\title{
IMPACT OF THE URBANIZATION ON COASTAL DUNE: CASE OF KHARROUBA, WEST OF AlgERIA
}

\section{RACHIDA SENOUCI ${ }^{1,2}$ AND NASR-EDDINE TAIBI ${ }^{1 *}$}

1 Université Abdelhamid Ibn Badis de Mostaganem, Laboratoire, Protection, Valorisation et Gestion des Ressources Marines et Littorales \& Systématique Moléculaire, Mostaganem, Algeria

2 Université d'Oran 2, EGEAT, Espace Géographique et Aménagement du Territoire, Oran, Algeria

\section{*Corresponding author, nasreddine.taibi@univ-mosta.dz}

Received on 29 January 2019

Received in revised form on 5 February 2019

Accepted on 5 February 2019

Editor: Maria Virginia Alves Martins, Universidade do Estado do Rio de

Janeiro, Brazil

\section{Abstract}

Despite the coming into force of the Algerian Littoral Law $02 / 2002$, which aimed the protection of the coast and a sustainable use of its resources, construction projects have been authorized on brittle unstable lithology. Relating to this, Kharrouba experienced a tremendous change during the period 2004-2012 due to a massive urbanization. Accordingly, expert's reports concerning the sustainability of construction projects as required by the Law 01-03-2003, were not sufficient. In this work, we analyzed the morphological coastal transformation of Kharrouba between 1989 and 2016 with particular interest in the decline of the dune due to a strong urban growth. For this purpose, a topographic map and Google Earth Pro pictures were used and processed in a geographical information system (SIG). The results of the diachronic analysis and the evolution of the coastal dune showed that the dune surface increased $23.82 \%$ between 1989 and 2004; a period marked by a low construction activity. On the other hand, the surface of the dune regressed 59.67\% during the period 2004-2012 that

\section{Introduction}

Coastal areas present a complex geomorphology, which is constituted by rocky and sandy features. According to Kim et al. (2009) and Martínez et al. (2013) marine and atmospheric forces influence the morphology of the beach and the fore dune. The littoral dune, being the extreme seaward edge of all terrestrial existence, plays a key role in the protection of the near land against the storm (Jenks, 2014; Muller et al., 2016); it is as well a reserve of sediment for the beach nourishment.

Coastal dune around the world undergoes many morphological changes as a consequence of anthropogenic pressure. Many authors report that sand
Citation:

Senouci, R., Taibi, N., 2019. Impact of the urbanization on coastal dune: Case of Kharrouba, west of Algeria. Journal of Sedimentary Environments, 4 (1): 90-98.

coincided with a major flat construction for the local population and secondary for the tourism. In addition to the environmental impact, the degradation of the dune led to more erosion, sediment balance disturbance of the beach, and coastal risk susceptibility. Moreover, the study area already experienced two landslides between 2012 and 2014 with negative socioeconomic consequences. A sustainable development of the coastal zone in Kharrouba and the province of Mostaganem should consider the environment and its protection as inevitable conditions for long-term economic activities. Therefore, the stakeholder of this region should comply with the existing laws regarding the preservation of the dune and the respect of the legally fixed distance between the coastline and a planned construction project.

Keywords: Algeria. Coast. Dune. Impact. Urbanization. SIG.

loss, construction of harbors for commercial purposes and touristic infrastructure seem to be the most important disturbing factors (Williams et al., 2001; Scarelli et al., 2017; Duffy et al., 2018;), which led to the decline of coastal dunes (Paskoff, 1994; Ghodbani, 2005).

In Algeria, 2/3 of the population is concentrated at the coast, which represents $5 \%$ of the country area (Bouroumi, 2014). From the seventies, this country knew a significant built-up development, especially in Algiers, Oran and Annaba cities, where the sandy coastal features have been transformed massively by the construction. Consequently, the Algerian legislation introduced the Littoral Law 02/2002 aiming to protect and to assess the 
coast as a natural resource (Ghodbani and Berrahi-Midoun, 2013; Taibi, 2016).

The present study is focused on Mostaganem, located in the north-western of Algeria. Due to the urbanization, tourism activities, and an excessive sand extraction for the construction, this area experienced a beach regression and disturbance in its sediment budget. The monitoring of the dune changes is an important task in order to understand the evolution of the coastal zone, its management, the loss of biodiversity and hazard assessment (Andrews et al., 2002; Falcucci et al., 2007).

This work aims to identify, and to quantify morphological changes of the coastal features in Kharrouba between 1987 and 2016. For this task, the applied methodology is based on the integration of geographical techniques such as the integration of historical cartographic documents treated and analyzed in a geographic information system (GIS). Last one is a powerful tool used as a monitoring of the spatiotemporal evolution of land use/land cover, landslide hazard assessment (Abdikan et al., 2016).

\section{Material and Methods}

\subsection{Study area}

This study was focused on the coast of Kharrouba, an agglomeration located in the province of Mostaganem, in the northwest of Algeria (Fig. 1). Accordingly, its morphology comprised cliffs, beaches, and extended dune that represents a significant landscape feature. Geologically, Kharrouba showed two distinct formations, Upper Cretaceous rocky cliffs in the northeast and quaternary sandy beaches, dune and alluvium in the southwest. The coastal area is built by mobile dune close to the beach and consolidated dune (Paleo dune) in the supra littoral zone.

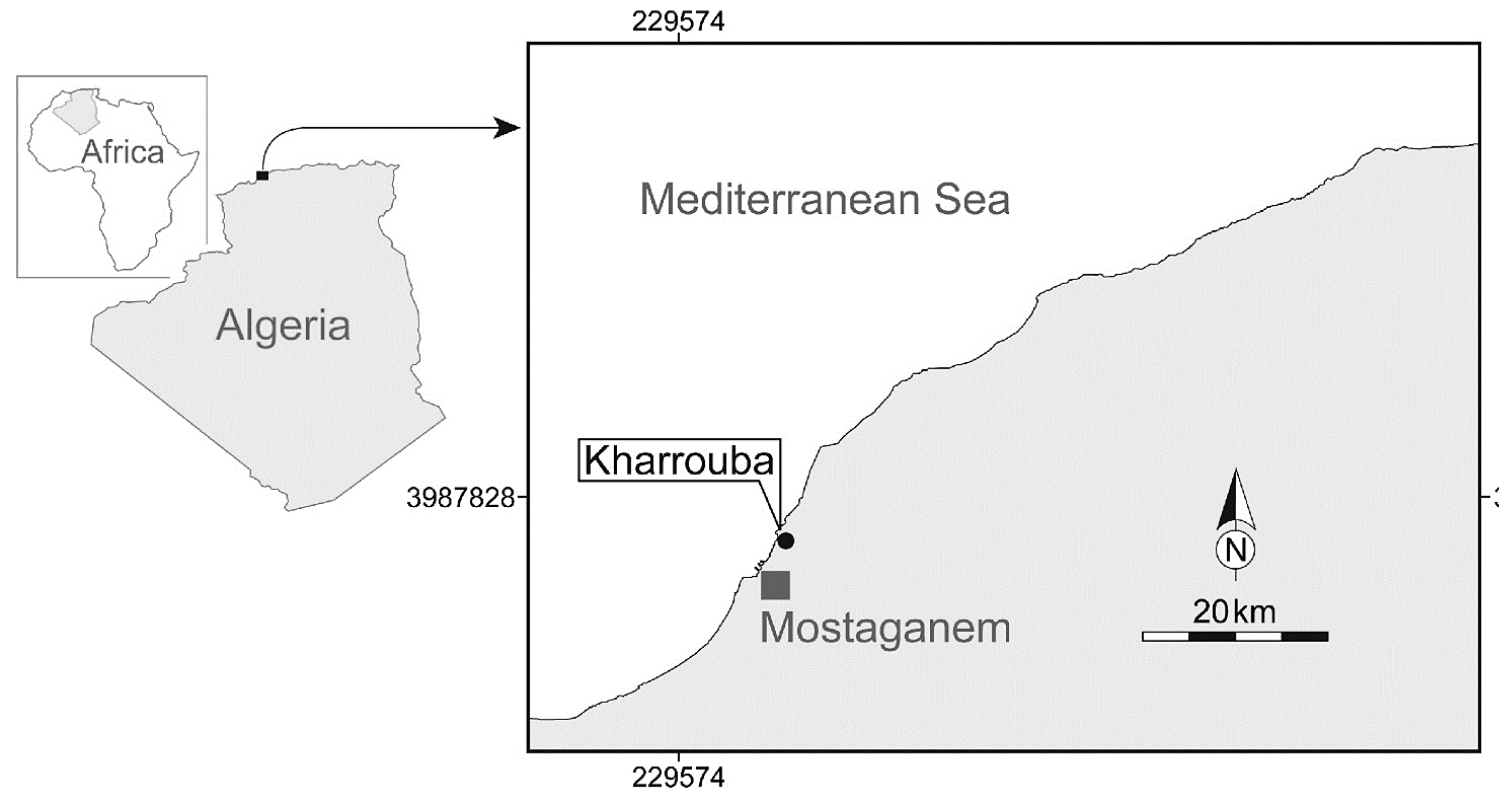

3987828

Fig. 1. Geographical setting of the study area.

\subsection{Methodology}

Different data and methods as historical maps, aerial photographs, satellite data processing, unmanned aerial vehicle (UAV), airborne Photogrammetry, GPS, DGPS and field survey are useful tolls to identify different transformations that occurred in the coastal area (Faye Ibrahima et al., 2008; Cohen et al., 2018). Kaliraj et al. (2017) used remote sensing and GIS techniques in order to monitor the different changes in the coast of Kanyakumari/India. Chaibi et al. (2013) identified changes in the littoral of El Djadida (Morocco) by means of aerial photography. Antso et al. (2013) used topographic map and field works to identify different pressures at coastal zones in Estonia. The present study aimed to identify and to quantify the evolution of the coastal dune of Kharrouba using Geographical Information system techniques (GIS). Generally, coastal dune changes frequently its shape because it is vulnerable to wind, wave and storms (Andrews et al., 2002). For this reason, we based on the vegetal cover as an indicator in order to delineate the coastal dune morphology and limit.

For this task, we used a 1/25000-scaled topographic map and images extracted from Google Earth Pro related to the periods 2004, 2012 and 2016. Cartographic data have been geometrically corrected and digitized; the area of the affected coastal features has been calculated using a GIS. Furthermore, the evolution of the dune and the consequences of the urbanization have been analyzed and mapped. In order to characterize the different surveyed 
dunes and its vegetal cover, we used the Corine Land Cover nomenclature, which is a computerized inventory to describe a land cover at a scale of 1/100000 and using 44 classes (Bossard et al., 2000; Feranec et al., 2007; Samaali, 2011). This nomenclature is structured in 3 levels regarding the resolution and this study goal (Acosta et al., 2005). The landslide event occurred in 2012 in Kharrouba has been analyzed using the report provided by the Directory of public works located in Mostaganem (DPW, 2012).

\section{Results}

The cartographic and GIS data on the spatiotemporal evolution of the coastal dune in Kharrouba let distinguish changes in the Paleo dune and the recent dune during the period 1989-2004, and drastic transformation between 2004 and 2012 (Fig. 2). The high demand on residential habitations for the local population led to massive construction among the dune or close to it twelve years long (2004-2016, Fig. 3). Consequently, the coastal environment experienced a considerable transformation, impacting the natural features formed by the recent dune and the consolidated dune (Paleo dune, Fig. 4). Whereas, the changes related to the built-up development occurred between 1989 and 2004 are minor than those registered in the period 2004-2012. The lost or gain resulting from the changes of the features is given in comparison to the total area of Kharrouba (Tables 1-3).
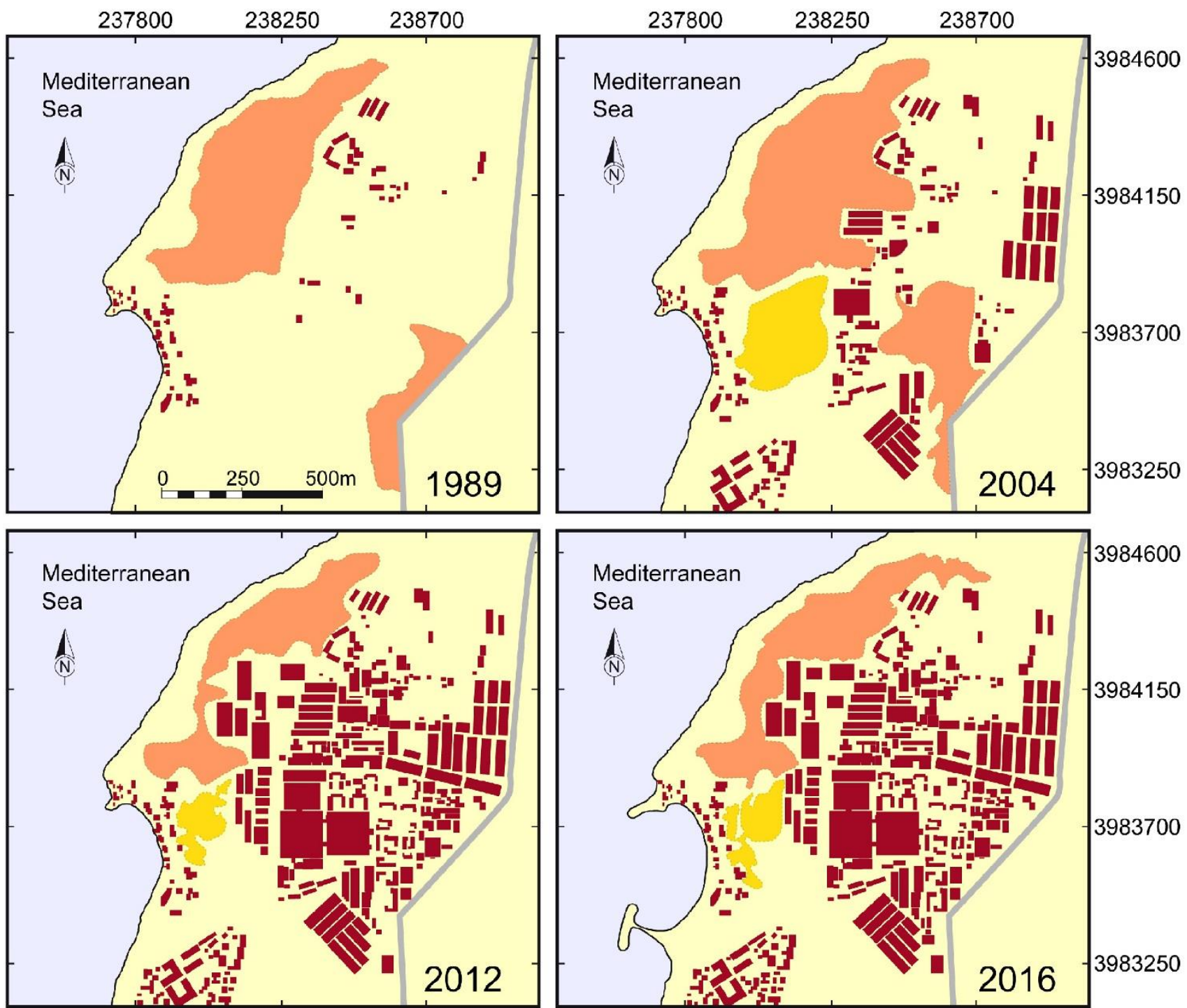

3984600

Densely vegetated dune Partially vegetated dune

Built-up surface

National Road

Fig. 2. Land cover changes in the coast of Kharrouba during the period 1989-2016. 

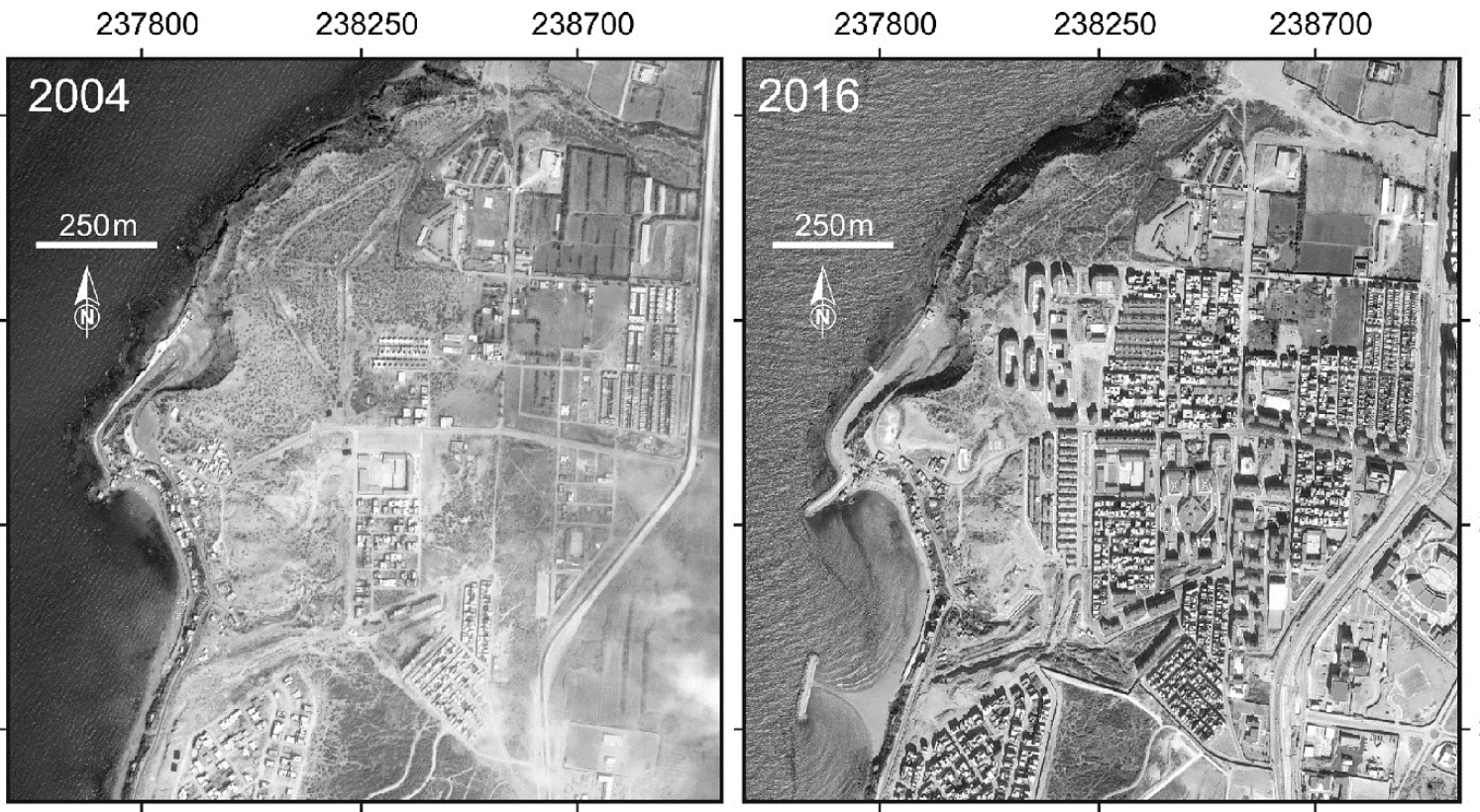

3984600

Fig. 3. Land cover changes in Kharrouba during the period 2004-2016 (Google Earth 2018).

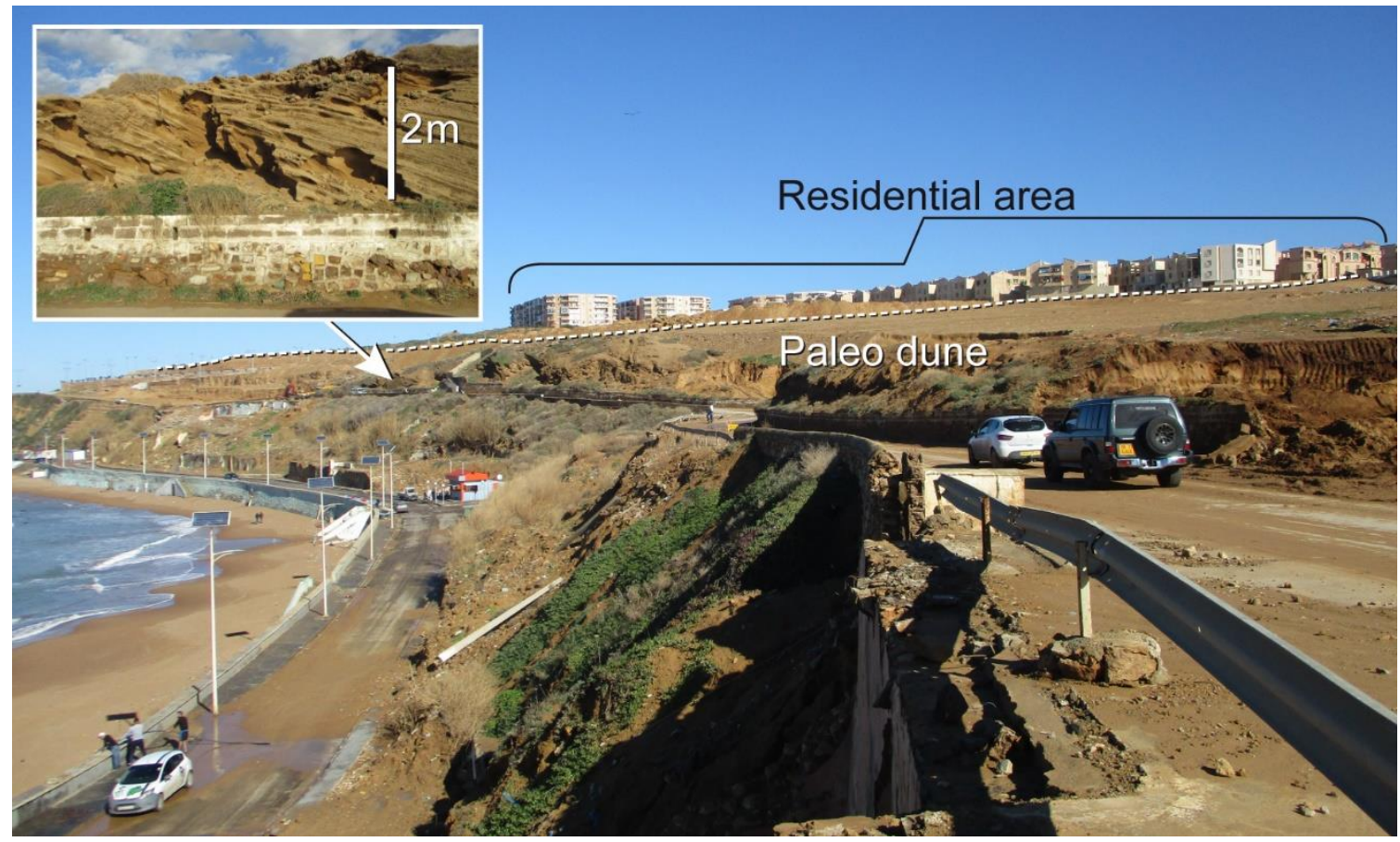

Fig. 4. Kharrouba is formed mainly by Paleo dune (NE-oriented photograph).

\subsection{Period 1989 - 2004}

The field survey showed that the sandy coast of Kharrouba is mainly occupied by recent dunes. Accordingly, this class presented a sporadic vegetal cover, which contributed to its identification.

Historically, the morphological situation in 1989 of the dunes had not been reported on the available topographic maps at that time. As an alternative, we used, a corresponding image extracted from Google Earth Pro.

During the period 1989-2004, the coast of Kharrouba enrolled a change in favor to the growth of densely vegetated dune. This feature represented $16 \%$ of the total area in 1989 and went up to $23.8 \%$ in 2004. The drastic change was registered in the built-up area, which increased $71.3 \%$ between 1989 and 2004 (Table 1). 


\subsection{Period 2004-2012}

During the period 2004-2012, the coast of Kharrouba experienced a crucial transformation that led to the urbanization of $32 \%$ of the total area as a response to the high demand for residential flats, stores and tourism structures. The coastal patterns underwent a significant alteration in this period despite the existing Littoral Law $02 / 2002$, which aimed to protect the coastal natural resources.

In 2004, the surface loss of the densely vegetated dune was $60 \%$ in ratio to the total study area. In the same period, partially vegetated dune suffered as well the construction activities; this class decreased about $67.4 \%$ of the total area (Fig. 5). Consequently, the built-up area increased $216.9 \%$ compared to its initial surface (Table 2).

\subsection{Period 2012-2016}

This period showed an irrelevant transformation because $2.2 \%$ of the total area of Kharrouba experienced changes. Accordingly, densely vegetated dunes increased $8.6 \%$; partially vegetated dune registered a gain of $23.9 \%$, and the built-up area $4.7 \%$ (Table 3); both classes of dune increased together $32.5 \%$ in ratio to the initial dune area. According to the field surveys, the situation of Kharrouba reflected the application of the
Littoral Law 02/2002 and the awareness of the local authorities regarding the environmental impact of the urbanization on the society.

\section{Discussion}

\subsection{Morphologic changes caused by the urbanization}

The morphologic and environmental changes occurred in Kharrouba as a result of an intense urbanization forced by a rapid growing population are not an isolated case.

Accordingly, Ghodbani (2009) reported a comparable issue that occurred in mean coastal cities of Algeria as a consequence of the permanent growing population. Bouroumi (2014), Cheruto et al. (2016) and $\mathrm{Li}$ et al. (2017) connected the land cover change in coastal areas with the population growth, tourism, and industrial development. According to the National Statistics Office (2010), Mostaganem town, including the coast of Kharrouba registered a rapid population growth between 1998 and 2008. The tourism activities also registered an increase of the visitant number that reached 11 million in the summer 2012 (Taibi, 2016).

Tab. 1. Coastal features change during the period 1989-2004. Legend: 1 Surface of densely vegetated dune; 2 Surface of partially vegetated dune; 3 Artificial surfaces.

\begin{tabular}{|l|c|c|c|c|}
\hline & $\mathbf{1 9 8 9} \mathbf{( m}^{\mathbf{2}} \mathbf{n}$ & $\mathbf{2 0 0 4} \mathbf{( m}^{\mathbf{2}} \mathbf{1}$ & Affected area $\left.\mathbf{( m}^{\mathbf{2}}\right)$ & Affected area $\mathbf{( \% )}$ \\
\hline $\mathbf{D V D}_{\mathbf{1}}$ & 296043 & 366565 & 70522 & 23.8 \\
\hline $\mathbf{P D V}_{\mathbf{2}}$ & - & 75834 & - & - \\
\hline $\mathbf{A R}_{3}$ & 18042 & 146757 & 128715 & 71.34 \\
\hline
\end{tabular}

Tab. 2. Coastal features change during the period 2004-2012. Legend: 1 Surface of densely vegetated dune; 2 Surface of partially vegetated dune; 3 Artificial surfaces.

\begin{tabular}{|l|c|c|c|c|}
\hline & $\mathbf{2 0 0 4}\left(\mathbf{m}^{\mathbf{2}}\right)$ & $\mathbf{2 0 1 2}\left(\mathbf{m}^{\mathbf{2}}\right.$ & Affected area $\left.\mathbf{( m}^{\mathbf{2}}\right)$ & Affected area $\mathbf{( \% )}$ \\
\hline $\mathbf{D V D}_{\mathbf{1}}$ & 366565 & 147830 & -218735 & -59.7 \\
\hline $\mathbf{P D V}_{2}$ & 75834 & 24746 & -51088 & -67.4 \\
\hline $\mathbf{A R}_{\mathbf{3}}$ & 146757 & 465098 & 318341 & 216.9 \\
\hline
\end{tabular}

Tab. 3. Coastal features change during the period 2012-2016. Legend: 1 Surface of densely vegetated dune; 2 Surface of partially vegetated dune; 3 Artificial surfaces.

\begin{tabular}{|c|c|c|c|c|}
\hline & $\left.\mathbf{2 0 1 2} \mathbf{( m}^{\mathbf{2}}\right)$ & $\mathbf{2 0 1 6} \mathbf{( m}^{\mathbf{2}}$ & Affected area $\left.\mathbf{( m}^{\mathbf{2}}\right)$ & Affected area (\%) \\
\hline $\mathbf{D V D}_{\mathbf{1}}$ & 147830 & 160529 & 12699 & 8.6 \\
\hline $\mathbf{P D V}_{\mathbf{2}}$ & 24746 & 30671 & 5925 & 23.9 \\
\hline $\mathbf{A R}_{\mathbf{3}}$ & 465098 & 486916 & 21818 & 4.7 \\
\hline
\end{tabular}

Compared with other regions of the Mediterranean context, the actual situation of the Province of Mostaganem reflects the socioeconomic development (Alonso et al, 2002; Megherbi, 2015; Ghodbani et al.,
2016; Taibi, 2016). The Algerian Ministry of Land-use Planning, Tourism, and Handicraft (2015) mentioned that the available host accommodation in 2014 could satisfy the demand of 11000 tourists whereas the 
Province of Mostaganem registered in the same year 10 million visitors during the summer. Consequently, the inadequacy between tourism demand and offer would probably lead the decision maker to build more host structure close to the shore, that would mean a progressive dune destruction in favor to the urbanization (Paskoff, 1994; Scarelli et al., 2017; Kim et al., 2017). In this period (2012-2016), two breakwaters have been constructed with the aim to protect the beach of Sidi Medjdoub, the most popular bathing site of Kharrouba, against the marine erosion; according to Rizzi et al. (2015), such a protection presented a weak resilience against storms and rainfalls.

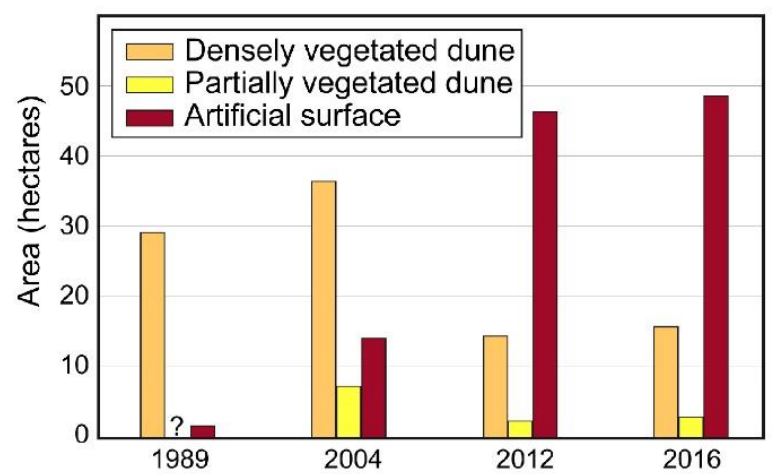

Fig. 5. Pattern evolution registered during the period 19892016 (Kharrouba).

The experience of the Spanish Mediterranean coast showed the impact caused by an intense urbanization close to the coastline that led to beach erosion and dune system regression. Garcia-Lozano et al. (2018) studied the historical transformation occurred in the coastal dune in Catalonia during the period 1890 to 1960. In this sense, the results evidenced the dunes disappearance or the advanced regression of those that remain today; $60 \%$ of the dunes disappeared and $30 \%$ of them retreated in size. In this context, the region of Barcelona was the most affected zone because $80 \%$ of the beaches lost their dunes. Furthermore, Girona and Tarragona enrolled, respectively, a loss of $60 \%$ and $40 \%$ of their dunes; nowadays, $10 \%$ of this feature remained pristine on the littoral of Catalonia. In the Northeast of the Italian Mediterranean Sea, Malavasi et al. (2013) focused their study on the evolution of the Landscape formed by coastal dunes and noted that $44 \%$ of the littoral morphology changed during the period 1954-1984 due to agriculture, afforestation and urbanization. However, Molise experienced a lower change (26\%) between 1984 and 2006. Long-term surveys highlighted the impact due to the transformation of a vulnerable feature such as dune and beach; different socioeconomic activities carried out close to the shoreline led to the alteration, and in extreme situations, to the definitive disappearance of the coastal dune. The Ministry of Land-use Planning,
RESEARCH PAPER

Tourism, and Handicraft created in the province of Mostaganem 16 tourist extension zones with the aim to develop seaside tourism activities; Kharrouba, being a coastal zone, will irremediably undergo this ruling. The construction of the necessary host accommodation to satisfy the tourism demand will continue to alter the dunes and to increase the landslide hazard.

\subsection{Coastal erosion and risk susceptibility in strong urbanized areas}

In order to improve the socioeconomic situation, the construction of host structures for the seaside tourism was the most valuable activity in different Mediterranean countries and this contributed to the disturbance of the coastal dune (Taibi, 2014; Comor et al., 2007; Toubes et al. 2017); accordingly, the coast of Kharrouba experienced the same issue. Consequently, the monitoring of the coastal evolution is a primordial tool for the stakeholder by making decisions on territory planning (Carboni et al., 2009). The anthropic alteration of the dune could change the balance of the sediment budget and lead to beach erosion. Since the eastern part of Kharrouba is strongly urbanized, the sediment transfer between the beach and the dune could not occur, and consequently increased the erosion process that affected the stability of the steep coastal slope; in January 2012, a landslide occurred producing socio-economic damages (Fig. 6), and two years later, another landslide has been registered in the same place producing the road subsidence (Fig. 7). These repetitive events showed obviously the vulnerability of the coast of Kharrouba in terms of static stability. Consequently, extreme weather conditions could generate in future other landslides combined with subsidence, especially the erosive action of the water flow within the sediment layer.

\section{Conclusion}

The use of a geographic information system (GIS) to monitor the morphological changes in the study area was a powerful tool that provided an evaluation of the natural surface lost during the period 1989-2016. In 27 years, the dune surface of Kharrouba retreated $39 \%$ due to an intense urbanization. Accordingly, it was necessary to satisfy the high demand on residential structures for the local population, however, it was the wrong decision to build among the dune owing to its vulnerability.

Despite the Algerian law, 01-03-2003 that regards the environmental feasibility of projects supposed to be carried out in a natural site or close to it, build-up activities happened and impacted the sandy coast. The same issue occurred in reference to the Algerian Littoral Law 02-2002 that aimed to protect the coastal zone against any activity with environmental damage. With respect to this, the 
terrain reality demonstrated that the control of the construction feasibility was unreliable in the province of Mostaganem. In addition to the environmental impact, the intense urbanization realized in Kharrouba on vulnerable terrain led to ground instability that produced landslides and road subsidence in 2012 and 2014; these repetitive events showed how difficult is to ensure the construction durability on the dune.

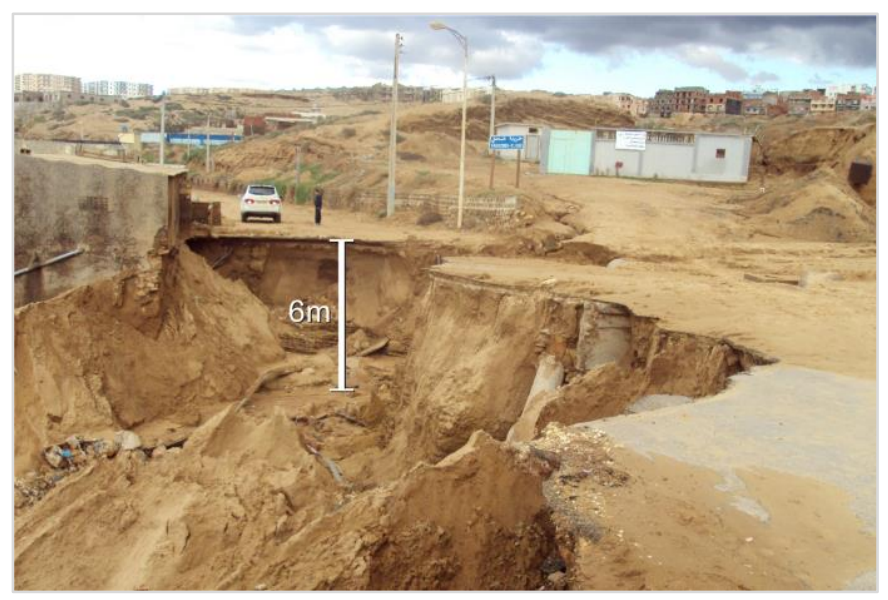

Fig. 6. Landslide in Kharrouba occurred in 2012 (DPW, 2012, NE-oriented photograph).

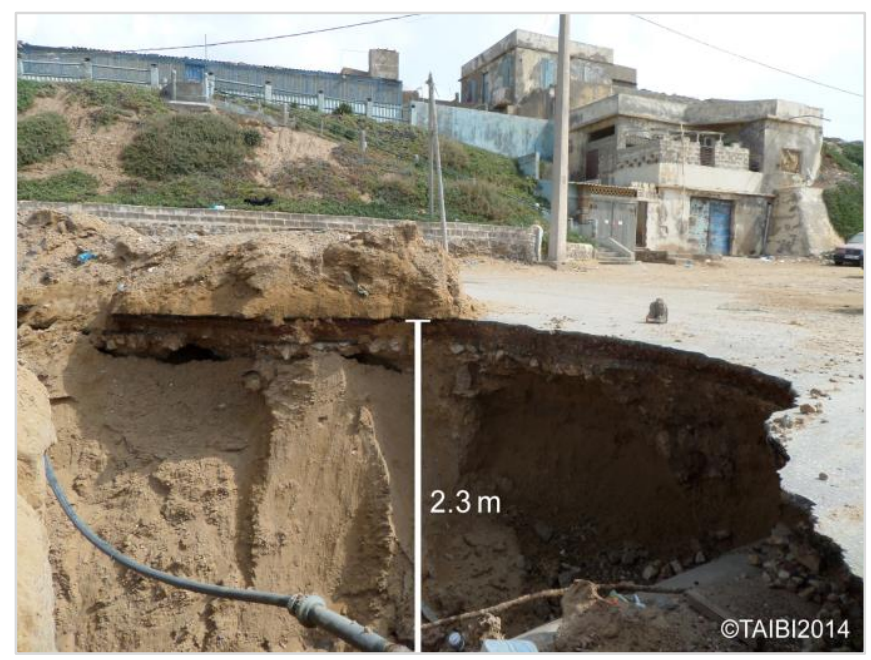

Fig. 7. Subsidence of the road produced by landslide (photograph taken on 17th April 2014).

The acquired study data can serve the stakeholder and the decision makers to handle adequately in terms of territory management, and rational use of the coastal resources. The development of the coast of Kharrouba should consider the (paleo) dune vulnerability to secure long-term economic activities and population safety.

In future, it is recommended to program the construction beyond the $300 \mathrm{~m}$ distance from the coastline as stipulated by the Algerian Littoral Law $02 / 2002$.

\section{Acknowledgment}

We thank the Directory of public works of the province of Mostaganem for it support.

\section{References}

Abdikan, S., Sanli, F.B., Ustuner, M., Calò, F., 2016. Land Cover Mapping Using Sentinel-1 SAR Data, Int. Arch. Photogramm. Remote Sensing Spatial Inf. Sci., XLI-B7, 757-761. https://doi.org/10.5194/isprs-archives-XLI-B7757-2016

Acosta, A., Carranza, M.L, Izzi, C.F., 2005. Combining land cover mapping of coastal dunes with vegetation analysis. Applied Vegetation Science 8, 133-138. https://doi.org/10.1111/j.1654-109X.2005.tb00638.x

Algerian Ministry of Land-use Planning, Tourism, and Handicraft 2015. Available at: http://www.okbob.net/article-le-site-officiel-duministeredu-tourisme-et-de-l-artisanat-algerie 89361166.html

Alonso, J. Alcántara-Carrió, Cabrera, L., 2002. Tourist Resorts and their Impact on Beach Erosion at Sotavento Beaches, Fuerteventura, Spain. Journal of Coastal Research: Special Issue 36 - International Coastal Symposium (ICS 2002): pp. 1 - 7. https://doi.org/10.2112/1551-5036-36.sp1.1

Andrews, B., Gares, P.A., Colby, J.D., 2002. Techniques for GIS Modeling of Coastal Dunes. Geomorphology 48, 289308. https://doi.org/10.1016/S0169-555X(02)00186-1

Antso, K., Kont, A., Palginõmm, V., Ratas, U., Rivis, R., Tõnisson, H., 2013. Changing natural and human impacts on the development of coastal land cover in Estonia. Journal of Coastal Research: Special Issue 65 - International Coastal Symposium, Volume 1, pp. 862 - 867. https://doi.org/10.2112/SI65-146.1

Bossard, M., Feranec, J., Otahel, J., 2000. CORINE land cover technical guide - Addendum 2000. Technical Report N 40, 105p. URL: http://www.geography.sav.sk/documents/2000feranec-corine.pdf

Bouroumi, M.T., 2014. Impact de l'urbanisation sur l'évolution du littoral Cas de la commune de Ain el Turk. Thèse de Magistère, 150 p., Université des Sciences et de la Technologie d'Oran.

Carboni, M., Carranza, M.L., Acosta, A., 2009. Assessing conservation status on coastal dunes: A multiscale approach. Landscape and Urban Planning 91, 17-25. https://doi.org/10.1016/j.landurbplan.2008.11.004

Chaibi, M., Ait Malek, H., Charif, A., Ayt Ougougdal, M., Maanan, M., 2013. Étude de l'évolution du littoral de la baie d'El Jadida (Maroc) par photo interprétation. Afrique Science 09 (2), 23.34. URL: https://www.ajol.info/index.php/afsci/article/view/112057

Cheruto M.C., Kauti M.K., Kisangau P.D., Kariuki P., 2016. Assessment of land use and land cover change using GIS and Remote Sensing Techniques: A case study of Makueni County, Kenya. Journal of Remote Sensing \& GIS 5, 175.

Cohen, O., Cartier, A., Ruz, M.-H., 2018. Mapping coastal dunes morphology and habitats evolution using UAV and ultra-high spatial resolution photogrammetry. International workshop "Management of coastal dunes and sandy beaches" 1-19. https://doi.org/10.13140/RG.2.2.19609.11360 
Comor, M., Orgeas, J., Ponel, P., Rolando, C., Delettre, Y.R., 2007. Impact of anthropogenic disturbances on beetle communities of French Mediterranean coastal dunes. Biodiversity and Conservation 17 (8), 1837-1852. doi.org/10.1007/s10531-007-9290-3

DPW (Directorate of Public Works), 2012. Album photo of Kharrouba landslide. URL: https://www.gettyimages.pt/fotos/landslide?sort=mostpo pular\&mediatype $=$ photography\&phrase $=$ landslide

Duffy, J.M., Shutler, J.D., Witt, M.J., DeBell, L., Anderson, K., 2018. Tracking fine-scale structural changes in coastal dune morphology using kite aerial photography and uncertainty-assessed structure-from-motion photogrammetry. Remote Sensing 10 (9), 1494, 1-21. https://doi.org/10.3390/rs10091494

Falcucci, A., Maiorano, L., Boitani, L., 2007. Changes in land use/land-cover patterns in Italy and their implications for biodiversity conservation. Landscape Ecology 22, 617-631 p. https://doi.org/10.1007/s10980-006-9056-4

Faye Ibrahima, B. ND., Henaff, A., Gourmelon, F., Amadou, T.D., 2008. Évolution du trait de côte à Nouakchott (Mauritanie) de 1954 à 2005 par photo-interprétation. https://doi.org/10.4000/norois.2146

Feranec, J., Hazeu, G., Christensen, S., Jaffrain, G., 2007. Corine land cover change detection in Europe (case studies of the Netherlands and Slovakia). Land Use Policy 24, 234247. https://doi.org/10.1016/j.landusepol.2006.02.002

Garcia-Lozano, C., Pintó, J., Daunis-i-Estadella, P., 2018. Changes in coastal dune systems on the Catalan shoreline (Spain, NW Mediterranean Sea). Comparing dune landscapes between 1890 and 1960 with their current status, Estuarine, Coastal and Shelf Science 208, 235-247. https://doi.org/10.1016/j.ecss.2018.05.004

Ghodbani, T., Kansab, O., Kouti.A., 2016. Développement du tourisme balnéaire en Algérie face à la problématique de protection des espaces littoraux. Le cas des côtes mostaganemoises. Tourisme et ressources naturelles. Etudes Caribéennes.https://journals.openedition.org/etudescarib eennes/9305

Ghodbani, T., Berrahi-Midoun, F., 2013. La littoralisation dans l'Ouest algérien: analyse multi scalaire des interactions hommes-espaces écosystèmes. Espace Populations Sociétés (ISSN: 2104-3752), p. 231-243.

Ghodbani, T., 2009. Environnement et littoralisation de l'Ouest algérien. PhD Thesis in Geography. 306 p., Université d'Oran ES-SENIA, Agérie, Université de PARIS 8 Vincennes Saint-Denis, FRANCE.

Ghodbani, T., 2005. Rechgoun, un espace à protéger sur le littoral ouest de l'Algérie, Méditerranée, https://doi.org/10.4000/mediterranee.350

Jenks, G., 2014. Affecting the functional capacity of coastal dune ecosystems 1 - utilizing New Zealand coastal dune degradation records as a proxy for analogous global impacts. A CLIM systems Technical Report. 20 p. URL: Http://Documents.Climsystems.Com/Publications/Affect ing_The_Functional_Capacity_Of_Coastal_Dune_Ecosyst ems_Utilising_New_Zealand_Coastal_Dune_Degradation _Records_As_A_Proxy_For_A.Pdf. (Accessed On 14 January 2019)
RESEARCH PAPER

Kaliraj, S., Chandrasekar, N., Ramachandran, K.K.., Srinivas, Y., Saravanan, S., 2017. Coastal land use and land cover change and transformations of Kanyakumari coast, India using remote sensing and GIS. The Egyptian Journal of Remote Sensing and Space Sciences 20 (2017) 18, 169-185. https://doi.org/10.1016/j.ejrs.2017.04.003

Kim, Y., Park, N-W., Lee, K-D., 2017. Self-Learning Based Land-Cover Classification Using Sequential Class Patterns from Past Land-Cover Maps. Remote Sensing 9(9), 921. https://doi.org/10.3390/rs9090921.

Kim, D., Yu, K.B., 2009. A conceptual model of coastal dune ecology synthesizing spatial gradients of vegetation, soil, and geomorphology. Plant Ecology 202, 135-148. https://doi.org/10.1007/s11258-008-9456-4

Li, X., Chen, G., Liu, X., Liang, X., Wang, S., Chen, Y., Pei, F., $\mathrm{Xu}, \mathrm{X}$, 2017. A new global land-use and land-cover change product at a $1-\mathrm{km}$ resolution for 2010 to 2100 based on human-environment interactions. Annals of the American Association of Geographers, https://doi.org/10.1080/24694452.2017.1303357

Littoral Law 02-2002 Loi relative à la Valorisation et la Protection du littoral. 5 février 2002, 7 p. Available at: http://www.jijel-archeo.123.fr/droit_algerien/loi_dz/loi0202.htm (Accessed on November, 15th 2015)

Malavasi, M., Santoro, R., Acosta, A.T.R., Carranza, M.L., 2013. What has happened to coastal dunes in the last half century? A multitemporal coastal landscape analysis in Central Italy. Landscape and Urban Planning 119, 54-63. http://dx.do0i.org/10.1016/j.landurbplan.2013.06.012

Martínez, M.L., Hesp, P.A., Gallego-Fernández, J.B., 2013. Coastal Dunes: Human Impact and Need for Restoration. https://doi.org/10.1007/978-3-642-33445-0_1

Megherbi, W., 2015. L’ensablement, un risque négligé en zone tellienne littorale Cas de la région Mostaganem. Thèse de Magistère. Université d'Oran 02.

Muller, H., Rooijen A.V., Idier, D., Pedreros, R., Rohmer, J., 2016. Assessing Storm Impact on a French Coastal Dune System Using Morphodynamic Modeling. Journal of Coastal Research 33 82), 254-273 (2016). https://doi.org/10.2112/JCOASTRES-D-15-00102

National office of Statistic 2010. Recensement Général de Population et de l'Habitat (RGPH) 1987, 1998 et 2008, Collection statistique $\mathrm{n}^{\circ}$ 87, wilaya de: Oran, Aïn'émouchent, Relizane, Mostaganem, Tiaret, Saïda, Mascara, Sidi Bel Abbes, Tlemcen, documents non publiés.

Paskoff, R., 1994. Les littoraux. Impact des aménagements sur leur évolution. Paris, Masson, 2e édition, 256 p. (ISBN 2225-84324-4)

Rizzi, J., Gallina, V., Torresan, S., Critto, A., Gana, S., Marcomini, A., 2015. Regional Risk Assessment addressing the impacts of climate change in the coastal area of the Gulf of Gabes (Tunisia). Sustainability Science 11, 455-476. https://doi.org/10.1007/s11625-015-0344-2

Samaali, H., 2011. Etude de l'evolution de l'occupation et de l'utilisation du sol dans le delta de Mejerda par télédétection et SIG. PhD Thesis in Cartography. Université de Tunis.

Scarelli, M.F., Sistillia, F., Fabbri, S., Cantellia, L., Barbozac, E.G., Gabbianelli, G., 2017. Seasonal dune and beach monitoring using photogrammetry from UAV surveys to apply in the ICZM on the Ravenna coast (Emilia- 
Romagna, Italy). Remote Sensing Applications: Society and Environment 7, 27-39. http://dx.doi.org/10.1016/j.rsase.2017.06.003

Taibi, N., 2016. Conflict between Coastal Tourism Development and Sustainability: case of Mostaganem, Western Algeria. European Journal of Sustainable Development 5 (4), 13-24. https://doi.org/10.14207/ejsd.2016.v5n4p13

Taibi, N., 2014. Impacts du tourisme de masse sur les plages Expérience de l'Espagne (Méditerranée). MarineScor Journal 1, 39-55.
RESEARCH PAPER

Toubes, D.R., Gössling, S., Michael Hall, C., Scott, D., 2017. Vulnerability of Coastal Beach Tourism to Flooding: A Case Study of Galicia, Spain. Environments 4 (4), 83; https://doi.org/10.3390/environments4040083

Williams, A.T., Alveirinho Dias, J., Novo Garcia, F., Garcia-Mora, J., Currd, R., Pereira, A., 2001. Integrated coastal dune management: checklists. Continental Shelf Research 21, 1937-1960. https://doi.org/10.1016/S0278-4343(01)00036-X 